\title{
Ficus sycomorus latex: An efficient alternative Egyptian source for horseradish peroxidase in labeling with antibodies for immunodiagnostic kits
}

\author{
Azza M. Abdel-Aty, Mohamed Belal Hamed, Abdul Aziz M. Gad, Amr E. El-Hakim and Saleh A. Mohamed \\ Molecular Biology Department, National Research Centre, Dokki, Cairo, Egypt. \\ Corresponding author: Azza M. Abdel-Aty, e-mail: azzasdm@hotmail.com \\ Co-authors: MBH: drbelal999@hotmail.com, AAMG: abdgad1983@yahoo.com, AEE: aselhakim@hotmail.com, \\ SAM: saleh38@hotmail.com
}

Received: 21-05-2018, Accepted: 16-08-2018, Published online: 01-10-2018

doi: 10.14202/vetworld.2018.1364-1370 How to cite this article: Abdel-Aty AM, Hamed MB, Gad AAM, El-Hakim AE, Mohamed SA (2018) Ficus sycomorus latex: An efficient alternative Egyptian source for horseradish peroxidase in labeling with antibodies for immunodiagnostic kits, Veterinary World, 11(10): 1364-1370.

\begin{abstract}
Aim: In view of various peroxidase applications, the searching for new sources of unique peroxidase properties is highly desirable. The present study aims to evaluate the efficiency of the peroxidase of locally grown sycamore latex (POL) for conjugation with antibodies and to study the conjugate optimal conditions, storage stability, and affinity toward different substrates as compared with commercial horseradish peroxidase (HRP).
\end{abstract}

Materials and Methods: Anti-mouse antibodies were prepared in rabbits and purified by protein A sepharose affinity column chromatography. The POL and HRP conjugates were prepared by one-step glutaraldehyde coupling method. The reactivity of the prepared conjugates was examined using the enzyme-linked immunosorbent assay (ELISA). The optimal enzymatic conditions, storage stability, and affinity toward substrates were also determined for both the conjugates.

Results: The POL showed higher percent recovery (98\%) than HRP (78\%) over the initial activity after conjugation process. The POL and HRP conjugates showed ELISA titers of 1:120 and 1:80, respectively, demonstrating high binding affinity of POL-conjugate. The POL-conjugate showed high thermal stability up to $70^{\circ} \mathrm{C}$ compared with HRP-conjugate up to $40^{\circ} \mathrm{C}$. After conjugation, POL had wide $\mathrm{pH}$ stability (5.0-8.0) compared with HPR (4.5-6.0). Both of the prepared conjugates had a high affinity toward the substrates used in immunoassays with lower $\mathrm{K}_{\mathrm{m}}$ values. The POL-conjugate showed high storage stability for its enzymatic activity and ELISA titer compared with HRP-conjugate after 1 year at $-20^{\circ} \mathrm{C}$.

Conclusion: The POL of Ficus sycomorus latex is an efficient source for labeling antibodies and could be utilized in immunodiagnostic kits.

Keywords: conjugation, Ficus sycomorus, horseradish peroxidase, immunodiagnostic assays, latex.

\section{Introduction}

Peroxidases (EC.1.11.1.7) are hydrogen peroxide decomposing enzymes associated with oxidation of the broad range of phenolic and non-phenolic substrates. Plant peroxidases have an essential physiological role in the growth and development of plant throughout its life cycle. Due to the versatility of peroxidases during reaction and their ubiquitous nature, they have potential applications in various immunological, medicinal, biotechnological, and industrial sectors [1-3].

Latex is a natural plant polymer flowed from various plant parts after having a tissue injury. It is a complex mixture of phytochemicals and unique enzymes that protect the plant against bacteria, fungi, viruses, and feeding insects [4]. Latex peroxidases have unique properties to perform a protective role against possible oxidative damage which begins after plant is wounded [5].

Copyright: Abdel-Aty, et al. Open Access. This article is distributed under the terms of the Creative Commons Attribution 4.0 International License (http://creativecommons.org/licenses/ by/4.0/), which permits unrestricted use, distribution, and reproduction in any medium, provided you give appropriate credit to the original author(s) and the source, provide a link to the Creative Commons license, and indicate if changes were made. The Creative Commons Public Domain Dedication waiver (http:// creativecommons.org/publicdomain/zero/1.0/) applies to the data made available in this article, unless otherwise stated.
Ficus sycomorus (Family: Moraceae) are short trees native to Africa. Its fruits (figs) widely used as a food and medicine all over the world [6-8]. Fig latex has potential therapeutic effects against several diseases [9]. Further, we previously purified and characterized peroxidase enzyme from locally grown sycamore fig latex (POL). This enzyme showed potent properties such as high thermal stability, broad $\mathrm{pH}$ optimum, and high affinity toward substrates commonly used in immunodiagnostic kits [10]. Moreover, POL was effectively decolorized industrially important synthetic and natural dyes [11].

From this standpoint, the present study aims to evaluate the efficiency of the POL enzyme, from locally grown sycamore fig latex, for conjugation with antibodies, and to study the conjugate optimal enzymatic conditions, its storage stability, its affinity toward different substrates, and its utility in enzymelinked immunosorbent assay (ELISA) as compared with commercial horseradish peroxidase (HRP).

\section{Materials and Methods}

\section{Ethical approval}

All the experimental protocols described in this study were performed in accordance with the 
recommendations of the Ethical Committee of National Research Centre (NRC), Egypt.

\section{Materials}

HRP, 2,2'-azino-bis (3-ethylbenzo-thiazoline-6-sulfonic acid) (ABTS), 4-chloro-1-naphthol (4C-1N), 3,3`,5,5 tetramethylbenzidine (TMB), o-phenylenediamine dihydrochloride (OPD), guaiacol, hydrogen peroxide, protein A Sepharose CL-4B column, and monoclonal mouse anti-albumin IgG were purchased from Sigma Scientific Services Co. All other chemicals and reagents were of analytical grade. The buffers were prepared according to Gomorie [12], and the final $\mathrm{pH}$ was checked by $\mathrm{pH}$ meter. The POL peroxidase was previously purified from locally grown F. sycomorus fruit latex [10].

\section{Peroxidase assay}

Peroxidase activity was carried out according to Miranda et al. [13]. The reaction mixture contains in $1 \mathrm{ml}: 8 \mathrm{mM} \mathrm{H}_{2} \mathrm{O}_{2}, 40 \mathrm{mM}$ guaiacol, $20 \mathrm{mM}$ sodium acetate buffer, $\mathrm{pH} 5.5$, and $0.1 \mathrm{ml}$ enzyme sample. The change in absorbance was measured at $470 \mathrm{~nm}$ and room temperature $\left(28-30^{\circ} \mathrm{C}\right)$ using a spectrophotometer. One unit of peroxidase activity was defined as the amount of enzyme which increases the optical density (OD) 1.0 per min under standard assay conditions.

\section{Preparation and purification of rabbit anti-mouse IgGs (AM IgGs)}

AM IgGs were prepared in rabbits according to Hudson and Hay [14]. Two rabbits (each $1.5 \pm 0.11 \mathrm{~kg}$ ) were immunized by four subcutaneous injections of $60 \mu \mathrm{g}$ of mouse $\mathrm{IgG}$ dissolved in $0.5 \mathrm{ml}$ saline at 3 -week intervals. The first dose was mixed with $0.5 \mathrm{ml}$ of complete Freund's adjuvant. The subsequent doses were mixed with $0.5 \mathrm{ml}$ of incomplete Freund's adjuvant. The rabbits were bled, and the antisera were separated, pooled, and purified using the protein A Sepharose CL-4B column $(1.6 \mathrm{~cm} \times 4 \mathrm{~cm})$ equilibrated and washed with $0.1 \mathrm{M}$ Tris- $\mathrm{HCl} \mathrm{pH}, 7.4$. The adsorbed proteins were eluted with $0.1 \mathrm{M}$ glycine-HCl, $\mathrm{pH} 2.9$, at a flow rate of $60 \mathrm{ml} / \mathrm{h}$ and monitored at $280 \mathrm{~nm}$. The active fractions that contained the purified AM IgGs were concentrated by $75 \%$ ammonium sulfate precipitation.

\section{Coupling of the AM IgGs with POL and HRP}

One-step coupling method was used according to Tresca et al. [15] with slight modifications in coupling ratio and dialysis buffer. The peroxidase enzyme $(1.5 \mathrm{mg})$ and AM IgGs $(0.75 \mathrm{mg})$ in $2 \mathrm{ml}$ of $0.1 \mathrm{M}$ phosphate buffer, $\mathrm{pH} 6.8$, were incubated for $2 \mathrm{~h}$ at room temperature $\left(28-30^{\circ} \mathrm{C}\right)$ with $50 \mu \mathrm{l}$ of $1 \%$ solution of glutaraldehyde under gentle stirring, and then, the mixture was dialyzed several times against $20 \mathrm{mM}$ Tris- $\mathrm{HCl}$ buffer, $\mathrm{pH} 7.4$, included $5 \mathrm{mM} \mathrm{CaCl}_{2}$ and $150 \mathrm{mM} \mathrm{NaCl}$. The solution was centrifuged at $16,000 \times \mathrm{g}$ for $20 \mathrm{~min}$ at $4^{\circ} \mathrm{C}$, and the precipitate was removed.

\section{ELISA}

The reactivity of the prepared conjugates was examined in 96-well microtiter plates using the
ELISA test described by Ricoux et al. [16]. Briefly, each well was coated overnight with $100 \mu \mathrm{l}$ of monoclonal mouse anti-albumin IgG $(0.5 \mu \mathrm{g}$ protein/well $)$ dissolved in coating buffer $(50 \mathrm{mM}$ sodium carbonate buffer, $\mathrm{pH}$ 9.6). Non-specific sites were blocked for $1 \mathrm{~h}$ by the addition of $100 \mu \mathrm{l}$ of the blocking solution $\left(2 \%\right.$ gelatin dissolved in coating buffer) at $37^{\circ} \mathrm{C}$. Each well was incubated with $100 \mu$ of serum albu$\min (1 \mu \mathrm{g} /$ well $)$ dissolved in washing buffer $(0.01 \mathrm{M}$ PBS, pH 7.4 containing $0.05 \%$ Tween-20) at $37^{\circ} \mathrm{C}$ for $1 \mathrm{~h}$. Serial dilutions $(100 \mu \mathrm{l})$ of the prepared conjugate dissolved in washing buffer were added and incubated at $37^{\circ} \mathrm{C}$ for $1 \mathrm{~h}$. Finally, $100 \mu \mathrm{l}$ of substrate buffer $(0.33 \mathrm{mg} \mathrm{OPD} / \mathrm{ml}$ dissolved in citrate buffer, $\mathrm{pH} 4.5$, containing $0.04 \% \mathrm{H}_{2} \mathrm{O}_{2}$ ) was added to each well, then the reaction was stopped after $20 \mathrm{~min}$ by the addition of $20 \mu 1$ of a 1:20 dilution of sulfuric acid and the absorbance was determined at $490 \mathrm{~nm}$ with ELISA reader. All the values were recorded in duplicate. A standard curve between log conjugate dilution and $\log \mathrm{OD}$ was plotted. The dilution that gives $0.5 \mathrm{OD}$. at $490 \mathrm{~nm}$ was taken as the ELISA titer.

\section{Characterization of conjugated enzyme properties}

The peroxidase activity standard assay was used to monitor the characterization of both the conjugated enzymes. The optimum $\mathrm{pH}$ was examined using $20 \mathrm{mM}$ of sodium acetate, sodium phosphate, and Tris-HCl buffers over a $\mathrm{pH}$ range of 3.5-6.0, 6.0-7.0, and 7.0-9.0, respectively. To examine the $\mathrm{pH}$ stability, the enzyme was incubated at the same $\mathrm{pH}$ buffers and room temperature $\left(28-30^{\circ} \mathrm{C}\right)$ for $2 \mathrm{~h}$ before substrate addition and measurement of the residual activity. The optimum temperature was examined by incubating the reaction mixture at different temperatures ranging from $10^{\circ} \mathrm{C}$ to $90^{\circ} \mathrm{C}$. The effect of temperature on the enzyme stability was examined by preincubating the enzyme for $30 \mathrm{~min}$ in different temperatures ranging from $10^{\circ} \mathrm{C}$ to $90^{\circ} \mathrm{C}$ before substrate addition, followed by cooling in ice bath, and the remaining activity was determined.

\section{Protein determination}

Protein concentration was quantified by the method of Bradford [17] using bovine serum albumin as a standard.

\section{Statistical analysis}

The results are reported as mean \pm standard error for at least 4 times' experiments.

\section{Results and Discussion}

Among peroxidases, HRP is commonly used for many analytical and industrial purposes. However, other plant peroxidases possessed better substrate specificities, broad $\mathrm{pH}$ and thermal stability, yield, and economic feasibility and could be optional for HRP [1]. The peroxidase of sweet potato has high specific activity and unique electrochemical characters as well as easily available; therefore, it is used as a biosensor [18]. Tobacco peroxidase was immobilized 
to graphite electrodes and used for the detection of aromatic compounds [19]. The peroxidase of spring cabbage has a strong preference toward various substrates, high thermal and $\mathrm{pH}$ stability, and low costs of extraction, so it is used as a bioelectrocatalysis [20]. Turnip root peroxidases have been used for uric acid detection kits [21]. The searching for new sources of unique peroxidase properties such as high stability toward temperature, $\mathrm{pH}$, and heavy metals, and high affinity toward broad substrates is highly desirable. These potent properties have been previously detected in the purified peroxidase (POL) of $F$. sycomorus fruit latex [10]. Further, the peroxidase has great ability to produce stable chromogenic products, so it is a suitable enzyme in various diagnostic kits based on enzyme-conjugated antibody technology $[1,22]$. Therefore, the present study is directed to prepare POL-conjugate with high storage stability and binding affinity toward substrates compared with commercial HRP-conjugate.

\section{Purification of rabbit IgGs}

The anti-immunoglobulins needed for conjugation with either POL or HRP peroxidases were prepared by injection of mouse IgG in rabbits using a traditional protocol according to Hudson and Hay [14]. Several methods were reported for the purification of serum $\mathrm{IgG}$; however, the affinity chromatography method is considered as a simple, one-step, and highly efficient method for IgG purification [23]. Therefore, the prepared sera were collected, pooled, and applied on a protein A Sepharose affinity column. In Figure-1a, the chromatographic profile of the protein A Sepharose column showed two protein peaks, the second peak (28-40 fractions) was pooled, concentrated by $75 \%$ ammonium sulfate precipitation and designated as a rabbit AM IgGs. A quantity of $24 \mathrm{mg}$ of AM IgGs was yielded from $4 \mathrm{ml}$ of rabbit antiserum. The purity of AM IgGs was confirmed by sodium dodecyl sulfate-polyacrylamide gel electrophoresis (Figure-1b). Similarly, a large amount of highly purified yield of $\mathrm{IgG}$ was previously reported when the protein A sepharose affinity method was used [24].

\section{Conjugation of purified POL and HRP to AM IgGs}

Enzyme-antibody conjugate is most often prepared by cross-linking between the enzyme and the antibody either by their functional groups or sugar moieties attached to one of the proteins. Therefore, the coupling with homobifunctional reagent such as

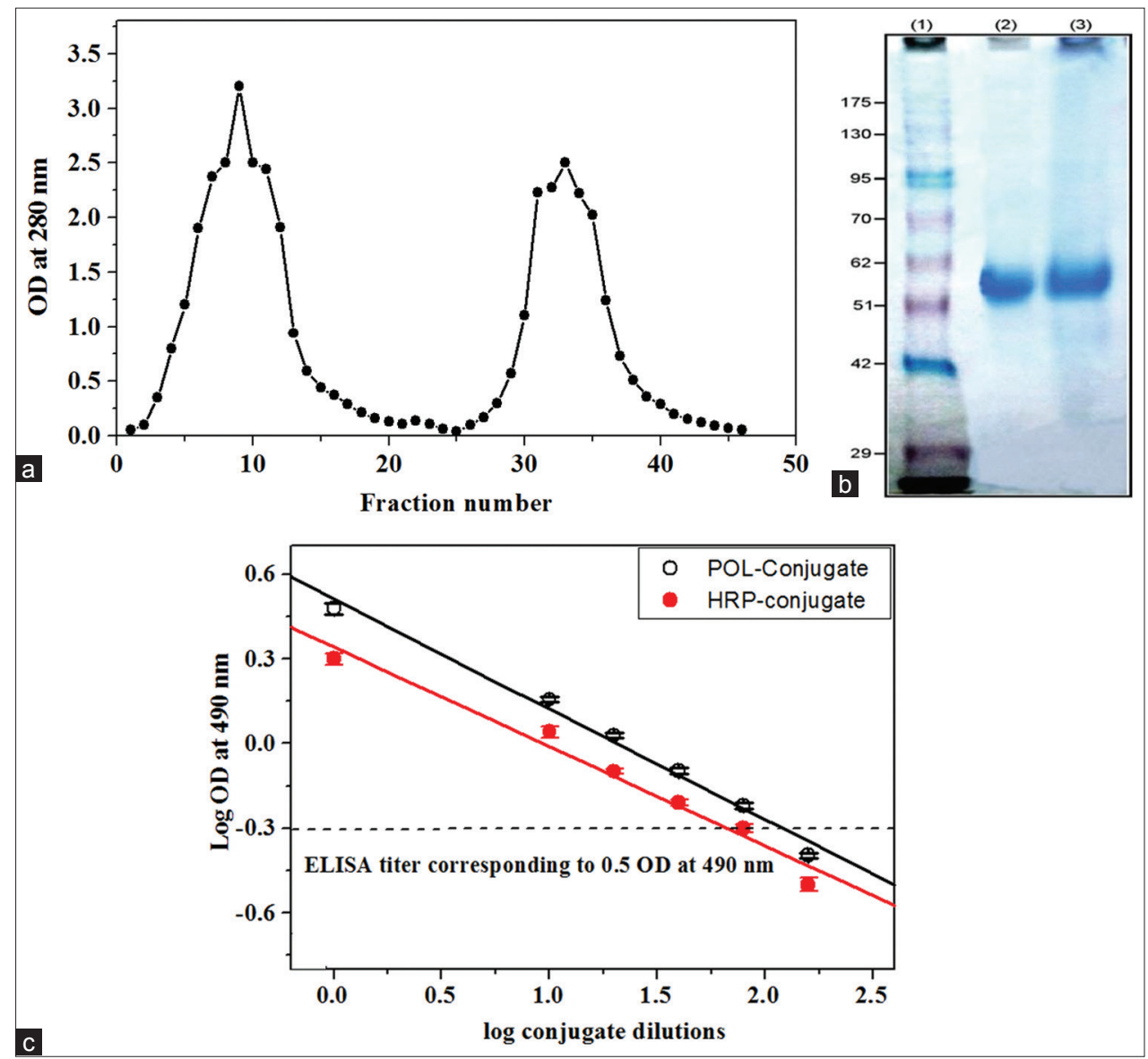

Figure-1: (a) Affinity chromatography of rabbit anti-mouse IgGs (AM IgGs) on a protein A Sepharose column $(1.6 \mathrm{~cm} \times 4 \mathrm{~cm})$. The unbound proteins were washed out by $0.1 \mathrm{M}$ Tris- $\mathrm{HCl}, \mathrm{pH} 7.4$, while the bound proteins were eluted with $0.1 \mathrm{M}$ glycine$\mathrm{HCl}, \mathrm{pH} 2.9$ at a flow rate of $60 \mathrm{ml} / \mathrm{h}$. (b) Sodium dodecyl sulfate-polyacrylamide gel electrophoresis (SDS_PAGE) of the purified AM IgGs. Lane (1): MW marker, Lanes (2 and 3): 5 and $10 \mu \mathrm{g}$ of the purified AM IgGs, respectively. (c) Enzymelinked immunosorbent assay (ELISA) titration curve of the prepared sycamore latex peroxidase (POL) and horseradish peroxidase (HRP) conjugates. $\log _{10}$ conjugate dilution versus $\log _{10} A_{490}$ is presented. The values represent mean \pm standard error $(n=4)$. 
glutaraldehyde is common $[25,26]$. Table- 1 shows the characteristics of POL and HRP peroxidases before and after conjugation process. At the beginning, either of POL or HRP peroxidase $(1.5 \mathrm{mg}$ protein $/ \mathrm{ml})$ with total activity (5000 and $8070 \mathrm{U}$ ) and specific activity (3333 and $5380 \mathrm{U} / \mathrm{mg}$ protein), respectively, were conjugated to $0.75 \mathrm{mg}$ of AM IgGs in a ratio of $2: 1(\mathrm{w} / \mathrm{w})$. After conjugation, the POL-IgG conjugate ( $2 \mathrm{mg}$ protein $/ \mathrm{ml}$ ) had total activity and specific activity of 4890 $\mathrm{U}$ and $2445 \mathrm{U} / \mathrm{mg}$ protein compared with the HRP-IgG conjugate $(2.2 \mathrm{mg}$ protein $/ \mathrm{ml}) 6250 \mathrm{U}$ and $2802 \mathrm{U} /$ mg protein, respectively. Further, the POL-conjugate showed higher percentage recovery $(98 \%)$ than the HRP-conjugate (78\%) over the initial activity. These results indicated that most of the POL enzymatic activities were retained after the coupling process, demonstrating that this method did not alter the functionality of the POL enzyme. However, the percentage recovery of Turnip-peroxidase (TPOD) coupled with antibodies by glutaraldehyde method was $58.5 \%$ [27]. The peroxidase of Brassica oleracea gongylodes also retained $54 \%$ of its activity after conjugation [28]. Here, to evaluate the binding affinity of the peroxidase enzyme to antibody and to quantify the concentration of antibody in each prepared conjugate, ELISA experiment was designed. The POL and HRP conjugates showed ELISA titer of 1:120 and 1:80, respectively (Figure-1c and Table-1), suggesting that the POLconjugate has greater binding affinity than the HRPconjugate. This is higher than a TPOD-conjugate of turnip which has a reported ELISA titer of 1:10 [27]. Differences in ELISA titers among conjugates were attributed to the differences of coupling methods, coupling ratio between antibody and the enzyme, the concentration of coupling agent and optimization conditions during conjugation process $[28,29]$.

\section{Characterization of the POL and HRP conjugates}

Both the POL and HRP had temperature optima at $40^{\circ} \mathrm{C}$, and they increased to 50 and $45^{\circ} \mathrm{C}$ after conjugation, respectively (Figure-2a and $b$ ). Further, the purified POL and POL-conjugate showed high thermal stability since no loss of activity was recorded up to 60 and $70^{\circ} \mathrm{C}$, respectively. However, the HRP and HRP-conjugate showed similar thermal stability up to $40^{\circ} \mathrm{C}$ (Figure-2c and d). The peroxidase resistance to temperature depends on the source of the enzyme and assay conditions [10]. Turnip TPOD-conjugate showed thermal stability up to $40^{\circ} \mathrm{C}$, and the activity

Table-1: Conjugation of the purified POL and HRP to AM IgG.

\begin{tabular}{|c|c|c|c|c|c|}
\hline Sample & Protein (mg) & Activity (U) & Specific activity (U/mg) & Recovery (\%) & ELISA titer \\
\hline$\overline{\mathrm{POL}}$ & 1.5 & 5000 & 3333 & 100 & - \\
\hline POL-IgG & 2 & 4890 & 2445 & 98 & $1: 120$ \\
\hline HRP & 1.5 & 8070 & 5380 & 100 & - \\
\hline HRP-IgG & 2.2 & 6250 & 2802 & 78 & $1: 80$ \\
\hline
\end{tabular}

ELISA=Enzyme-linked immunosorbent assay, HRP=Horseradish peroxidase, AM IgG=Anti-mouse IgG, POL= Sycamore latex peroxidase

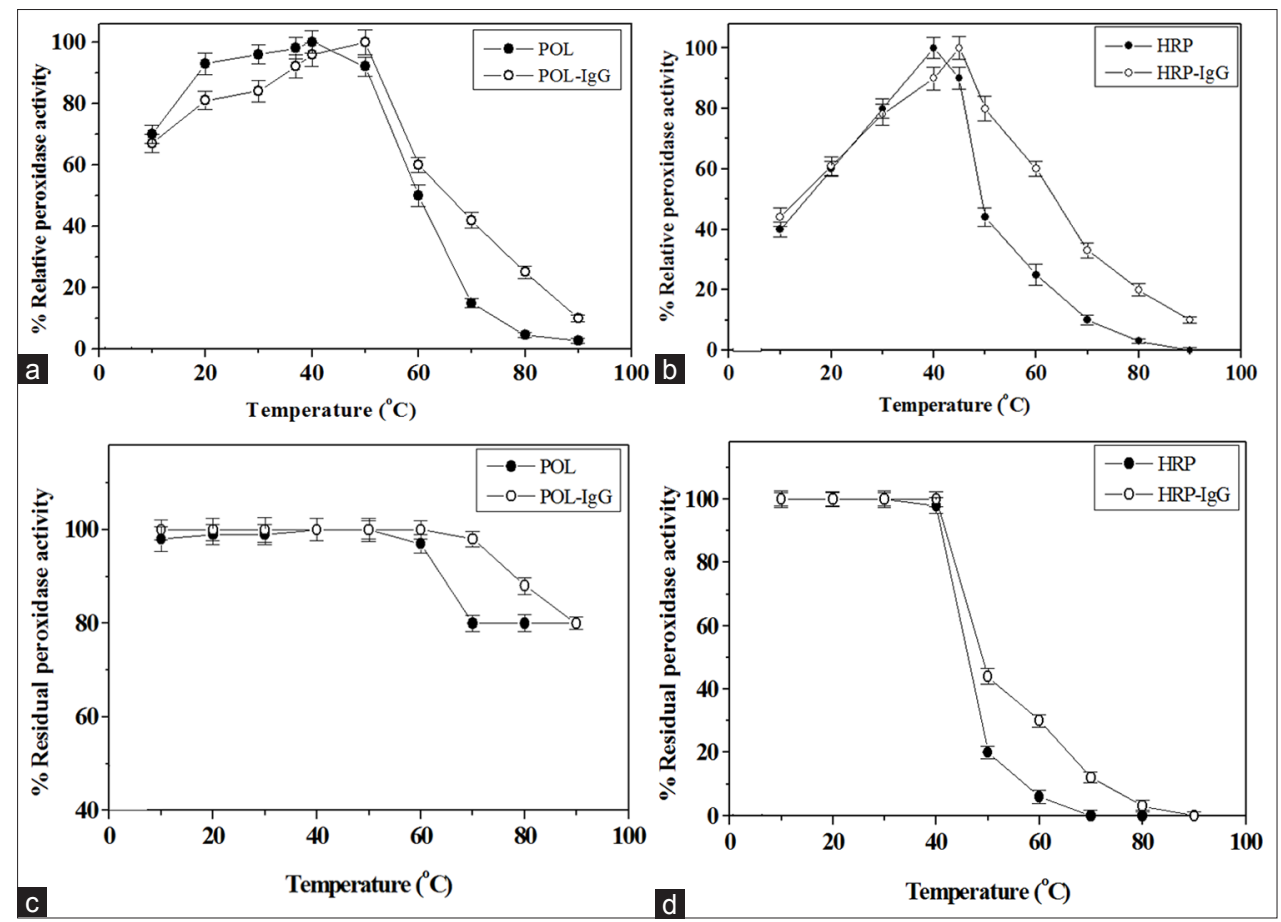

Figure-2: Typical profiles for the assessment of the optimum temperature ( $a$ and b) and thermal stability (c and d) of the sycamore latex peroxidase (POL) and horseradish peroxidase (HRP) before and after conjugation process. The values represent mean \pm standard error $(n=4)$. 
decreased with increasing temperature up to $65^{\circ} \mathrm{C}$ [27]. The peroxidase-conjugate of $B$. oleracea gongylodes possessed thermal stability up to $50^{\circ} \mathrm{C}$ [28].

The POL, HRP, and HRP-conjugate possessed the same $\mathrm{pH}$ optima at 5.5, while it became a broad (5.5-6.5) in case of POL-conjugate (Figure-3a and b). Both of the purified TPOD and TPOD-conjugate prepared by glutaraldehyde method exhibited the same $\mathrm{pH}$ optima at 3.5 [27]. The $\mathrm{pH}$ stability of the POL and HRP was broad (5-7 and 4.5-5.5), while it was increased to 5-8 and 4.5-6, respectively, after conjugation (Figure-3c and $\mathrm{d}$ ). The $\mathrm{pH}$ stability of the peroxidase of $B$. oleracea gongylodes improved after conjugation [28]. It was observed that the POL relative peroxidase activity was higher than the HRP activity in most characterization assays, while the HRP possessed slightly higher relative peroxidase activity than $\mathrm{POL}$ at $\mathrm{pH}$ ranges (3.5-5.0 and 8.0-9.0). Table- 2 summarizes the most measured parameters of the prepared conjugates compared to POL and HRP enzymes.
The effect of different concentrations of substrates (ABTS, 4C-1N, OPD, and TMB) that commonly used in immunodiagnostic kits on the prepared conjugates was also studied. In Table-2, both the POL and HRP conjugates exhibited lower $\mathrm{K}_{\mathrm{m}}$ values using ABTS, 4C-1N, OPD, and TMB (3.8, 4.3, 4.8, and 6.4 and $4.0,5.9,4.6$, and $3.7 \mathrm{mM}$ ) than that of POL and HRP (4.5, 5.0, 5.8, and 7.0 and 4.3, 6.2, 5.0, and $4.0 \mathrm{mM}$ ), respectively. It is likely that the prepared conjugates retained their high affinity toward the substrates which used in immunoassays. Lower $\mathrm{K}$ value using ABTS was previously reported for the TPODconjugate [27]. The peroxidase-conjugate of $B$. oleracea gongylodes also showed low $\mathrm{K}_{\mathrm{m}}$ values to phenol and BCP and BTB dyes [28].

The storage stability of the prepared conjugates was evaluated by measuring both of the ELISA titer and enzyme activity percentage during 12 months at $-20^{\circ} \mathrm{C}$. In Figure-4, the POL-conjugate showed $100 \%$ stability for its enzyme activity and ELISA titer
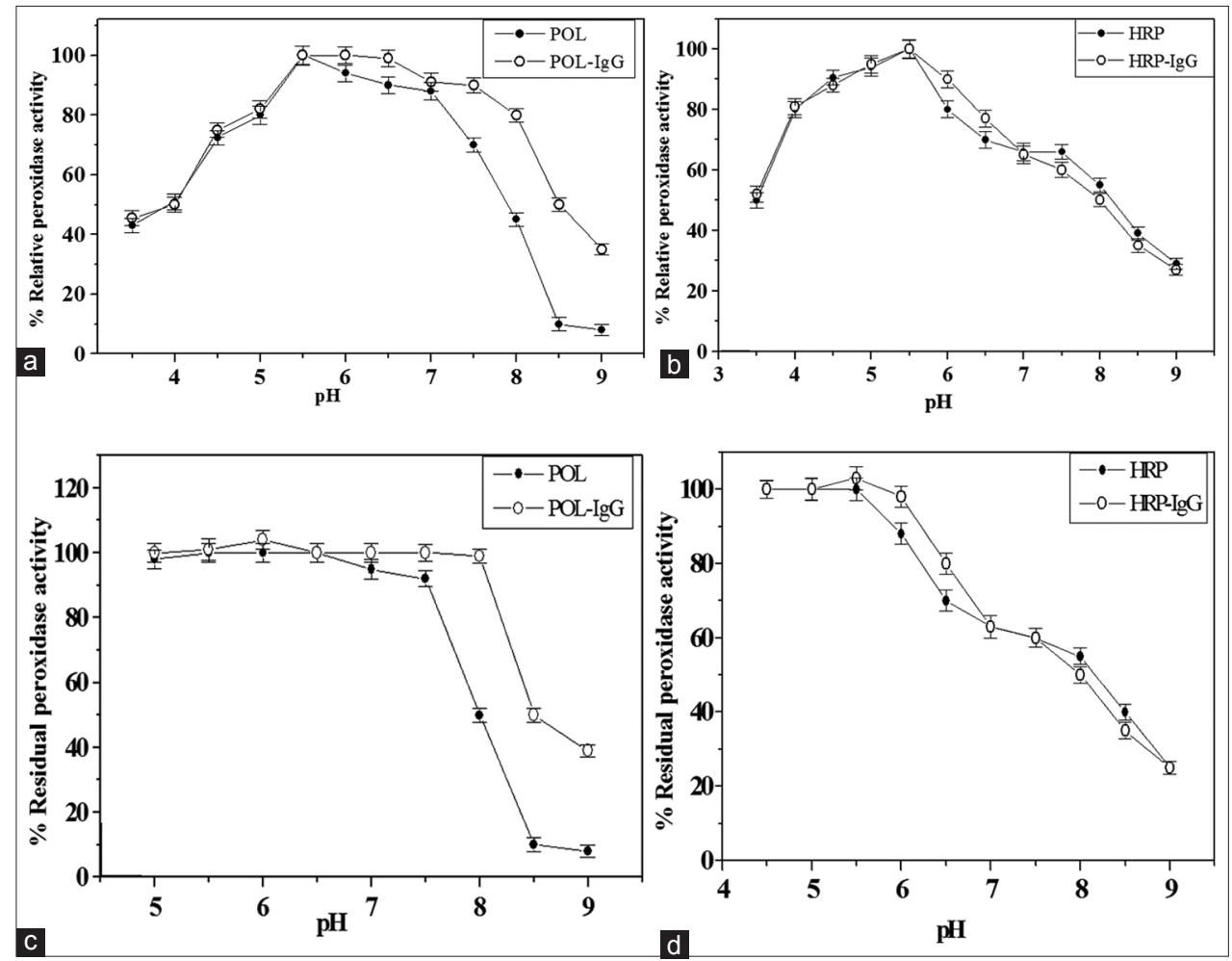

Figure-3: Typical profiles for the assessment of the optimum $\mathrm{pH}$ ( $\mathrm{a}$ and $\mathrm{b}$ ) and $\mathrm{pH}$ stability (c and d) of the sycamore latex peroxidase (POL) and horseradish peroxidase (HRP) before and after conjugation process. The values represent mean \pm standard error $(n=4)$.

Table-2: Physical and kinetic studies of the POL and HRP before and after conjugation with AM-IgG.

\begin{tabular}{|c|c|c|c|c|c|c|c|c|}
\hline \multirow[t]{2}{*}{ Sample } & \multirow[t]{2}{*}{ Optimum pH } & \multirow[t]{2}{*}{ pH stability } & \multirow{2}{*}{$\begin{array}{c}\text { Optimum } \\
\text { temperature }\end{array}{ }^{\circ} \mathrm{C}$} & \multirow{2}{*}{$\begin{array}{c}\text { Thermal } \\
\text { stability }{ }^{\circ} \mathrm{C}\end{array}$} & \multicolumn{4}{|c|}{$K_{m}$ (mM substrates) } \\
\hline & & & & & ABTS & $4 C-1 N$ & OPD & TMB \\
\hline$\overline{\mathrm{POL}}$ & 5.5 & $5.0-7.0$ & 40 & $10-60$ & $4.5 \pm 0.5$ & $5.0 \pm 0.6$ & $5.8 \pm 0.4$ & $7.0 \pm 0.8$ \\
\hline POL-IgG & $5.5-6.5$ & $5.0-8.0$ & 50 & $10-70$ & $3.8 \pm 0.63$ & $4.3 \pm 0.52$ & $4.8 \pm 0.5$ & $6.4 \pm 0.4$ \\
\hline HRP & 5.5 & $4.5-5.5$ & 40 & $10-40$ & $4.3 \pm 0.67$ & $6.2 \pm 0.4$ & $5.0 \pm 0.32$ & $4.0 \pm 0.7$ \\
\hline HRP-IgG & 5.5 & $4.5-6.0$ & 45 & $10-40$ & $4.0 \pm 0.52$ & $5.9 \pm 0.67$ & $4.6 \pm 0.41$ & $3.7 \pm 0.4$ \\
\hline
\end{tabular}

Values are presented as means \pm standard error $(n=4)$. HRP $=$ Horseradish peroxidase, $P O L=$ Sycamore latex peroxidase, $A B T S=2,2$ '-Azino-bis (3-ethylbenzo-thiazoline-6-sulfonic acid), OPD=0-phenylenediamine dihydrochloride, $4 \mathrm{C}-1 \mathrm{~N}=4$-chloro-1-naphthol, $\mathrm{TMB}=3,3^{`}, 5,5^{`}$ tetramethylbenzidine, AM-IgG=Anti-mouse IgG 


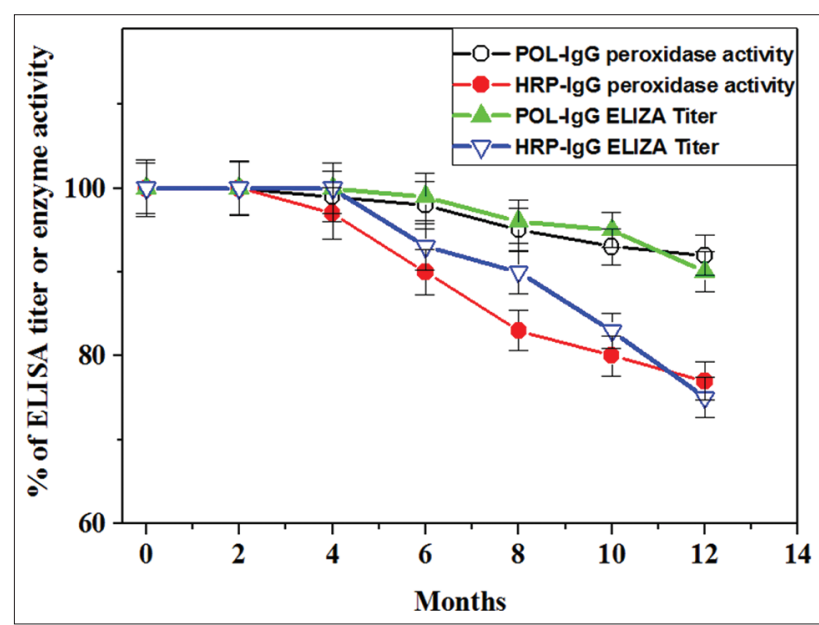

Figure-4: Storage stability assessment of the prepared sycamore latex peroxidase (POL) and horseradish peroxidase (HRP) conjugates during 1 year at $-20^{\circ} \mathrm{C}$. The values represent mean \pm standard error $(n=4)$.

up to 6 months compared with HRP-conjugate $90 \%$. Furthermore, only $8-10 \%$ activity and binding titer of the POL-conjugate were lost up to 12 months compared with HRP-conjugate (23-25\%), respectively. Moreover, a strong correlation between the enzyme activity and binding titer of both conjugates was observed. The HRP-conjugate using cyanuric chloride showed no change in ELISA titer during 12 months when it stored at $-70^{\circ} \mathrm{C}$ [29]. The TPODconjugate of turnip showed $20 \%$ loss of enzyme activity over 6 months at $-20^{\circ} \mathrm{C}$ [27]. The HRP labeled by anti-camel $\operatorname{IgG}$ showed stable activity for 1 year at $-20^{\circ} \mathrm{C}[30]$. The peroxidase-conjugate of $B$. oleracea gongylodes retained $95 \%$ of enzyme activity after 2 months when stored at $-20^{\circ} \mathrm{C}$ [28].

\section{Conclusion}

From the current study, F. sycomorus latex peroxidase (POL) and HRP conjugates were prepared using glutaraldehyde coupling method. In comparison with the prepared HRP-conjugate, the POL-conjugate retained most of its enzymatic activity and showed greater binding affinity. Further, the POL enzyme parameters (temperature and $\mathrm{pH}$ optima and thermal and $\mathrm{pH}$ stability) were improved after conjugation. The POL-conjugate showed high storage stability for 1 year at $-20^{\circ} \mathrm{C}$. Both of the prepared conjugates retained their high affinity toward the immunodiagnostic kit substrates with low $\mathrm{K}_{\mathrm{m}}$ values. Consequently, the POL peroxidase enzyme is an efficient Egyptian source in labeling with antibodies for immunodiagnostic kits.

\section{Authors' Contributions}

AMA, MBH, AEE, and SAM had the original idea for the study and carried out the design. AMA, $\mathrm{MBH}$, and AAMG were responsible for data analysis, data cleaning, and writing the manuscript. The final draft manuscript was revised by all authors.All authors read and approved the final manuscript.

\section{Acknowledgments}

The authors gratefully acknowledge the National Research Centre, Cairo, Egypt, for providing the facilitation and equipment throughout the study. The authors declare that they did not receive any funding source to support their study.

\section{Competing Interests}

The authors declare that they have no competing interests.

\section{References}

1. Pandey, V.P., Awasthi, M., Singh, S., Tiwari, S. and Dwivedi, U.N. (2017) A comprehensive review on function and application of plant peroxidases. Biochem. Anal. Biochem., 6: 1-16.

2. Pandey, V.P. and Dwivedi, U.N. (2015) A ripening-associated peroxidase from papaya having a role in defense and lignification: Heterologous expression and in-silico and in-vitro experimental validation. Gene, 555: 438-447.

3. Chandrasekaran, G., Choi, S.K., Lee, Y.C., Kim, G.J. and Shin, H.J. (2014) Oxidative biodegradation of single-walled carbon nanotubes by partially purified lignin-peroxidase from Sparassis latifolia mushroom. J. Ind. Eng. Chem., 20: $3367-3374$

4. Van der Horn, R.A.L. and Jones, J.D.G. (2004) The plant proteolytic machinery and its role in defense. Curr. Opin. Plant Biol., 7: 400-407.

5. Kawano, T. (2003) Roles of the reactive oxygen species-generating peroxidase reactions in plant defense and growth induction. Plant Cell Rep., 21: 829-837.

6. Belguith-Hadriche, O., Ammar, S., Contreras, M.M., Turki, M., Segura-Carretero, A., El Feki, A., MakniAyedi, F. and Bouaziz, M. (2016) Antihyperlipidemic and antioxidant activities of edible Tunisian Ficus carica L. fruits in high fat diet-induced hyperlipidemic rats. Plant Foods Hum. Nutr., 71: 183-189.

7. Mawa, S., Husain, K. and Jantan, I. (2013) Ficus carica L. (Moraceae): Phytochemistry, traditional uses and biological activities. Evid. Based Complement. Altern. Med., Article ID: 974256: 8 .

8. Amessis-Ouchemoukh, N., Ouchemoukh, S., Mezianta, N., Idiria, Y., Hernanzc, D., Stincod, C.M., Rodríguez-Pulido, F.J., Heredia, F.J., Madania, K. and Luis, J. (2017) Bioactive metabolites involved in the antioxidant, anticancer and anticalpain activities of Ficus carica L., Ceratonia siliqua L. and Quercus ilex L. extracts. Ind Crops Prod., 95: 6-17.

9. Lansky, E.P., Paavilainen, H.M., Pawlus, A.D. and Newman, R.A. (2008) Ficus spp. (fig): Ethnobotany and potential as anticancer and anti-inflammatory agents. $J$. Ethnopharmacol., 119: 195-213.

10. Mohamed, S.A., Abdel-Aty, A.M., Hamed, M.B., El-Badry, M.O. and Fahmy, A.S. (2011) Ficus syncomorus latex: A thermostable peroxidase. Afr. J. Biotech., 10: 17532-17543.

11. Abdel-Aty, A.M., Hamed, M.B., Fahmy, A.S. and Mohamed, S.A. (2013) Comparison of the potential of Ficus sycomorus latex and horseradish peroxidases in the decolorization of synthetic and natural dyes. J. Genet. Eng. Biotechnol., 11: 95-102.

12. Gomorie, G. (1955) Preparation of buffers for use in enzyme studies. Methods Enzymol., 3: 357-363.

13. Miranda, M.V., Fernandez, L.H.M. and Cascone, O. (1995) Horseradish peroxidase extraction and purification by aqueous two-phase partition. Appl. Biochem. Biotechnol. 53: 147-154.

14. Hudson, L. and Hay, F.C. (1989) Practical Immunology. $3^{\text {rd }}$ ed. Blackwell Scientific, Philadelphia, PA. 
15. Tresca, J.P., Ricoux, R., Pontet, M. and Engler, R. (1995) Comparative activity of peroxidase-antibody conjugates with periodate and glutaraldehyde coupling according to an enzyme-immunoassay. Ann. Biol. Clin., 53: 227-231.

16. Ricoux, R., Chazaud, B., Tresca, J.P. and Pontet, M. (2000) Quality control of coated antibodies: New, rapid determination of binding affinity. Clin. Chem. Lab. Med., 38: 239-243.

17. Bradford, M.M. (1976) A rapid and sensitive method for the quantitation of microgram quantities of protein utilizing the principle of protein-dye binding. Anal. Biochem., 72: $248-254$

18. Lindgren, A., Ruzgas, T., Gorton, L., Csoregi, E., Bautista, A.G., Sakharov, I.Y. and Gazaryan, I.G. (2000) Biosensors based on novel peroxidases with improved properties in direct and mediated electron transfer. Biosens. Bioelectron., 15: 491-497.

19. Castillo, J., Ferapontova, E., Hushpulian, D., Tasca, F., Tishkov, V., Chubar, T., Gazaryan, I., Gorton, L. (2006) Direct electrochemistry and bioelectrocatalysis of $\mathrm{H}_{2} \mathrm{O}_{2}$ reduction of recombinant tobacco peroxidase on graphite. Effect of peroxidase single-point mutation on $\mathrm{Ca}^{2+}$ modulated catalytic activity. J. Electroanal. Chem., 588: 112-121.

20. Belcarz, A., Ginalska, G., Kowalewska, B. and Kulesza, P. (2008) Spring cabbage peroxidases-potential tool in biocatalysis and bioelectrocatalysis. Photochemistry, 69: 627-636.

21. Agostini, E., Hernandez-Ruiz, J., Arnao, M.B., Milrad, S.R., Tigier, H.A. and Acosta, M. (2002) A peroxidase isoenzyme secreted by turnip (Brassica napus) hairy-root cultures: Inactivation by hydrogen peroxide and application in diagnostic kits. Biotechnol. Appl. Biochem., 35: 1-7.

22. Shivakumar, A., Jashmitha, B.G. and Dhruvaraj, M.R. (2017) Role of peroxidase in clinical assays: A short review.
Am. J. Clin. Nutr., 3: 2-14.

23. Mariam, S.H.S., Ooi, C.W., Tan, W.S., Janna, O.A., Arbakariya, A. and Tey, B.T. (2015) Purification of rabbit polyclonal immunoglobulin $\mathrm{G}$ with ammonium sulphate precipitation and mixed-mode chromatography. Sep. Purif. Technol. J., 144: 133-138.

24. Blanc, M.R., Anouassi, A., Abed, M.A., Canépa, S., Labas, V. and Bruneau, G. (2009) A new method to discriminate immunogen-specific heavy-chain homodimer from heterotetramer immunoglobulin G directly in immunized dromedary whole plasma proteins: Western ligand blotting. Vet. Immunol. Immunopathol. J., 127: 340-349.

25. Avrameas, S. and Ternynck, T. (1969) The cross-linking of proteins with glutaraldehyde and its use for the preparation of immunoadsorbents. Immunochemisty, 6: 53.

26. Simons, B., Kaplan, H. and Hefford, M.A. (2006) Novel cross-linked enzyme-antibody conjugates for Western blot and ELISA. J. Immunol. Methods, 315: 88-98.

27. Hamed, R.R., Mohamed, T.M., EL Hakim, A.E. and Gad, A.M. (2009) Biochemical studies on the conjugation of antibodies with turnip peroxidase using two different methods. J. Biol. Res. Thessalon., 12: 173-186.

28. Shetty, P., D'Souza, A. and Geethu, C.P. (2017) Conjugation of peroxidase from Brassica oleracea gongylodes for use as a label-prospect of a novel enzyme tag for immunoassay systems. Int. J. Appl. Sci. Biotechnol., 5: 59-65.

29. Abuknesha, R.A., Luk, C.Y., Griffith, H.H.M., Maragkou, A. and Iakovaki, D. (2005) Efficient labeling of antibodies with horseradish peroxidase using cyanuric chloride. $J$. Immunol. Methods, 306: 211-217.

30. Abdel-Rahman, E.H., El-Jakee, J.K., Hatem, M.E., Ata, N.S. and Fouad, E.A. (2017) Preparation of goat and rabbit anticamel immunoglobulin $\mathrm{G}$ whole molecule labeled with horseradish peroxidase. Vet. World, 10: 92-10.

$* * * * * * * *$ 